\title{
ANALISA PENGGUNAAN LAHAN DAERAH PENGEMBANGAN POTENSI PANAS BUMI DI KECAMATAN SEMPOL, BONDOWOSO
}

\author{
Melisa Amalia Mahardianti, Muhammad Taufik, Widya Utama \\ Jurusan Teknik Geomatika, Fakultas Teknik Sipil dan Perencanaan \\ Institut Teknologi Sepuluh Nopember Surabaya (ITS) \\ Jl. Arief Rahman Hakim, Surabaya 60111 Indonesia \\ Email : taufik_srmd@yahoo.com,widutama@yahoo.fr
}

\begin{abstract}
Abstrak
Kawasan Gunung Ijen, Kecamatan Sempol, Bondowoso memiliki potensi panas bumi yang cukup besar. Dalam kegiatan eksplorasi dan eksploitasi panas bumi sangat berdampak pada keadaan lingkungan karena lokasi panas bumi berada di kawasan hutan produksi, kawasan hutan lindung, dan kawasan hutan konservasi. Untuk itu, diperlukan analisa penggunaan lahan di lokasi potensi panas bumi sebelum dilakukan pembangunan PLTP dan fasilitas penunjangnya.

Hasil penelitian ini menunjukkan bahwa terdapat tiga area yang berpotensi untuk pemanfaatan energi panas bumi. Potensi sumber daya panas bumi yang dapat membangkitkan energi listrik melalui Pembangkit Listrik Tenaga Panas Bumi dengan kapasitas 2 × $55 \mathrm{MW}$. Penggunaan lahan pada area tersebut sebagian besar terdiri dari semak belukar (42.53\%), dan jarak terdekat dengan pemukiman lebih dari $600 \mathrm{~m}$. Kegiatan eksplorasi diharapkan tidak berdampak negatif pada lingkungan sekitar.
\end{abstract}

Kata Kunci-panas bumi, penggunaan lahan, Citra Landsat ETM+, Peta RBI Digital, Sistem Informasi Geografis

\section{PENDAHULUAN}

\section{Latar Belakang}

Energi panas bumi, adalah energi panas yang tersimpan dalam batuan di bawah permukaan bumi dan fluida yang terkandung didalamnya (Saptadji). Dengan menggunakan SIG diharapkan akan mempermudah para pengambil keputusan untuk mengetahui penggunaan lahan pada kawasan potensi panas bumi di Kecamatan Sempol. Karena dengan adanya SIG akan digambarkan letak lokasi potensi panas bumi pada kondisi sesungguhnya dalam hal ini adalah peta Kecamatan Sempol.

Penelitian ini digunakan dengan menggunakan citra Landsat ETM 7 tahun 2003 untuk mengetahui estimasi suhu permukaan tanah. Untuk memetakan suhu permukaan darat, maka yg digunakan adalah band $61(10,4-12,5$ $\mu \mathrm{m})$. Band 6 juga berfungsi sebagai band thermal infrared. Pembuatan Digital Elevation Model (DEM) dari peta vektor RBI skala 1:25000 untuk klasifikasi ketinggian lahan yang dikorelasikan dengan suhu permukaan tanah. Korelasi tersebut menghasilkan suatu anomali suhu yang menjadi salah satu indikasi adanya manifestasi panas bumi. Peta Rupa Bumi Indonesia digital Kecamatan Sempol juga digunakan untuk mengidentifikasi kelas penutup lahan, sehingga peta dapat dihasilkan peta penggunaan lahan potensi panas bumi yang dapat membantu dalam kegiatan eksplorasi dan pengembangan lapangan panas bumi di wilayah Kecamatan Sempol. Sebagaimana tujuan dari penelitian ini adalah menentukan lokasi potensi panas bumi dan menganalisis penggunaan lahan di wilayah potensi panas bumi Kecamatan Sempol dengan memanfaatkan Sistem Informasi Geografis. 


\section{METODE PENELITIAN}

Lokasi yang digunakan pada penelitian ini terletak di Kecamatan Sempol, Kabupaten Bondowoso.

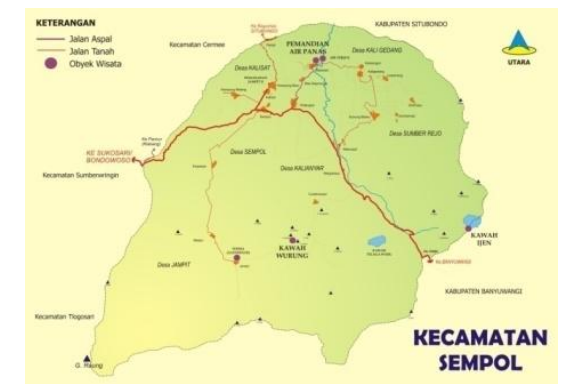

Gambar 1. Lokasi Penelitian

(BAPPEDA Kabupaten Bondowoso, 2010)

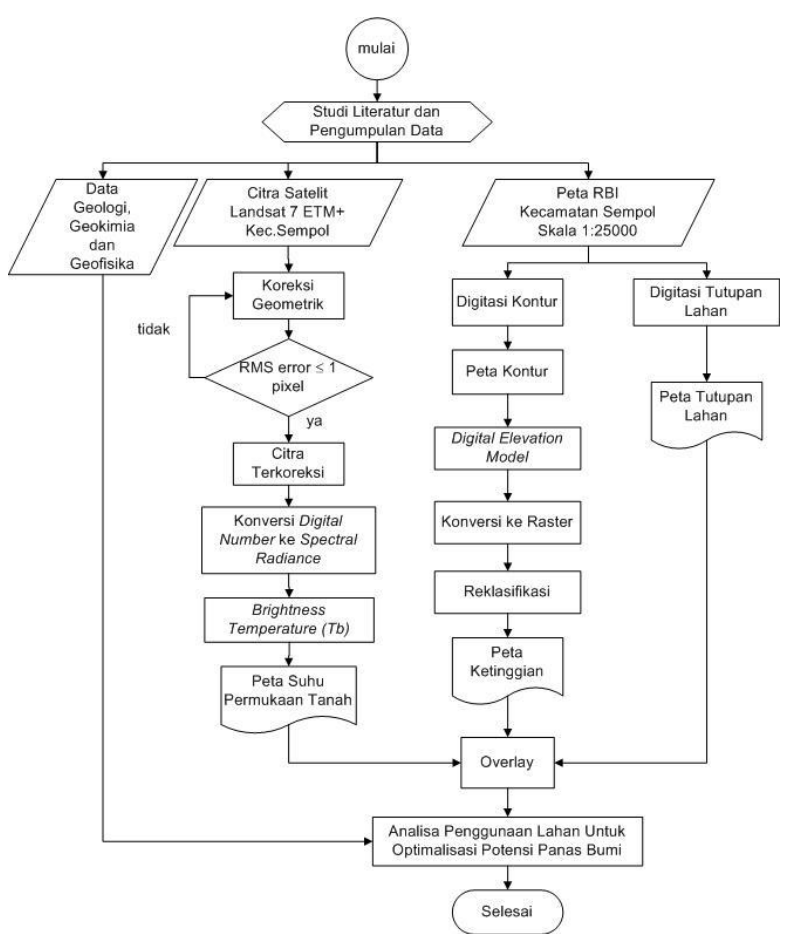

Gambar 2. Diagram Alir Pengolahan Data

Penentuan lokasi potensi panas bumi dilakukan dengan menggunakan metode penginderaan jauh dengan memanfaatkan citra satelit Landsat ETM 7 tahun 2003 menggunakan algoritma suhu permukaan tanah pada band thermal (band 6). Peta RBI digital untuk idenfitikasi tutupan lahan dan pembuatan DEM dengan ketelitian 12,5 meter sehingga didapat klasifikasi ketinggian lahan. Sehingga dari kondisi suhu permukaan tanah, ketinggian dan tutupan lahan dapat menentukan prakiraan area potensi panas bumi. Analisa yang diperlukan adalah analisa korelasi antara suhu permukaan tanah dan nilai klasifikasi ketinggian lahan, analisa lokasi potensi panas bumi, analisa kondisi lingkungan dan jarak lokasi potensi panas bumi dengan daerah sensitif dengan memanfaatkan Sistem Informasi Geografis. Dari tahapan diatas akan dapat diperoleh penggunaan lahan di wilayah potensi panas bumi Kecamatan Sempol.

\section{HASIL DAN PEMBAHASAN}

\section{Hasil Klasifikasi Tutupan lahan dari Peta RBI Digital}

Proses pengolahan untuk kelas tutupan lahan pada peta RBI digital yaitu dengan cara digitasi. Hasil dari digitasi tersebut terdiri dari enam kelas yang ditunjukkan pada tabel 1

Tabel 1. Luas Area Tutupan Lahan Tahun 2000

\begin{tabular}{lll}
\hline No. & Tutupan Lahan & Luas $(\mathrm{Ha})$ \\
\hline 1 & Tegalan & 706.927 \\
2 & Vegetasi Non Budidaya & 35.532 \\
3 & Semak Belukar & 8503.29 \\
4 & Pemukiman & 106.011 \\
5 & Padang Rumput & 3406.029 \\
6 & Kebun & 4491.72 \\
7 & Kawah & 54.3 \\
8 & Hutan Rimba & 4244.101 \\
& Jumlah & 21547.91 \\
\hline
\end{tabular}

\section{Hasil Klasifikasi Ketinggian Lahan}

Klasifikasi ketinggian lahan diperoleh dari hasil digitasi kontur dari peta RBI digital yang kemudian dikonversi kedalam format TIN kemudian direklasifikasi sesuai dengan kelas ketinggian yang telah ditentukan sehingga diperoleh informasi ketinggian wilayah penelitian.

Tabel 2. Kelas Ketinggian daerah penelitian

\begin{tabular}{ll}
\hline No. & Kelas Ketinggian \\
\hline 1 & $800-1013.75$ \\
2 & $1013.75-1227.5$ \\
3 & $1227.5-1441.25$ \\
4 & $1441.25-1655$ \\
\hline 5 & $1655-1868.75$
\end{tabular}




\begin{tabular}{ll}
6 & $1868.75-2082.5$ \\
7 & $2082.5-2296.25$ \\
8 & $2296.25-2510$ \\
9 & $2510-2723.75$ \\
10 & $2723.75-2937.5$ \\
\hline
\end{tabular}

\section{Koreksi Geometrik}

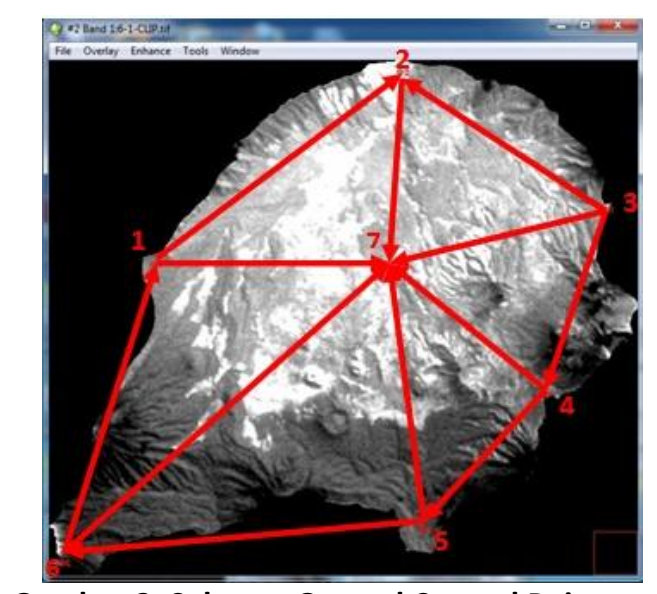

Gambar 3. Sebaran Ground Control Point

Untuk koreksi geometrik diberikan toleransi nilai RMSE $\leq 1$ piksel dan untuk jaring titik kontrol ditentukan dengan meletakkan titik-titik kontrol yang merata mencakup daerah studi dengan nilai toleransi SOF mendekati nol (Sukojo, 2012).

Hasil koreksi Geometrik yang dilakukan dengan 7 titik GCP yaitu nilai total RMS Error 0, 437845 . Perhitungan SOF (Strength of Figure) jaring tersebut adalah :

Jumlah Baseline $\quad: 12$

Jumlah Titik $\quad: 7$

N Ukuran : Jumlah Baseline $\times 3$

$: 12 \times 3=36$

N Parameter : Jumlah Titik $\times 3$

$: 7 \times 3=21$

$\mathrm{u} \quad$ :N Ukuran - N Parameter

$\begin{aligned} & : 36-21=15 \\ \text { Besar SOF } & : \frac{\text { Trace }\left[A^{T} x A\right]^{-1}}{u}\end{aligned}$

$: 0,4500$

\section{Suhu Permukaan Tanah dari Citra}

Suhu permukaan tanah merupakan kenampakan rata-rata dari suhu yang berada di permukaan tersebut. Pada umumnya, semakin tinggi daerah tertentu, maka suhu permukaan daratnya akan semakin menurun. Hal ini karena
Karakteristik dari adalah terjadinya penurunan suhu dengan adanya kenaikan ketinggian, dengan adanya penambahan jarak dari radiasi panas bumi. Dengan ketiadaan pencemaran udara komposisi troposfer sangat homogen, tetapi kandungan air di troposfer sangat bervariasi. Hal ini disebabkan oleh pembentukan awan, pengendapan, dan penguapan dari air yang berasal dari daerah terrestrial dan badanbadan air (Rodrigue, 2000).

Salah satu prospek dari manifestasi panas bumi adalah terdapat suatu anomali dari hasil pengolahan suhu permukaan dibandingkan dengan daerah disekitarnya. Hal ini dicurigai sebagai kawasan tempat keluarnya fluida panas dari reservoir ke permukaan (Wahyudi, 2005).

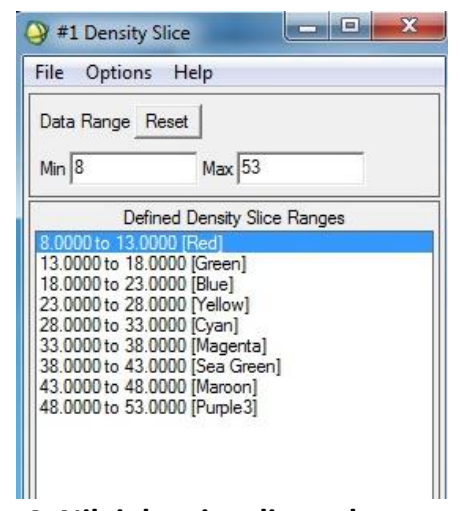

Gambar 4. Nilai density slice suhu permukaan

\section{Analisa Korelasi Suhu Permukaan Tanah dengan Ketinggian Lahan}

Analisa Korelasi bertujuan untuk mengetahui hubungan antara dua variabel atau lebih. Dalam penelitian ini, analisa korelasi digunakan untuk mengetahui hubungan antara tingkat kerapatan vegetasi dengan ketinggian dan kemiringan lahan. Analisa korelasi dihitung menggunakan persamaan uji korelasi Karl Pearson:

$$
r=\frac{n \sum X_{i} Y_{i^{-}}\left(\sum X_{i}\right)\left(\sum Y_{i}\right)}{\sqrt{\left\{n \sum X_{i}^{2}-\left(\sum X_{i}\right)^{2}\right\}\left\{n \sum Y_{i}^{2}-\left(\sum Y_{i}\right)^{2}\right\}}}
$$

\section{Keterangan:}

$r=$ koefisien korelasi

$\mathrm{n}=$ banyaknya pengamatan

$X_{i}=$ Nilai variabel untuk suhu permukaan tanah

$Y_{i}=$ nilai variabel untuk ketinggian dan lahan [5]. 
Tabel 3. Pedoman Interpretasi Koefisien Korelasi [6]

\begin{tabular}{ll}
\hline Interval Koefisien & Tingkat Hubungan \\
\hline $0,00-0.199$ & Sangat rendah \\
$0.20-0.339$ & Rendah \\
$0,40-0.599$ & Sedang \\
$0.60-0.799$ & Kuat \\
$0.80-1,00$ & \\
\hline
\end{tabular}

Penentuan analisis korelasi dilakukan dengan cara mengambil secara acak sebanyak 45 titik sampel yang mewakili penyebaran suhu permukaan tanah pada berbagai kelas ketinggian lahan. Analisis korelasi ketinggian lahan dengan suhu permukaan adalah :

Tabel 4. Korelasi Suhu Permukaan Tanah dan Ketinggian Lahan

\begin{tabular}{lll}
\hline \multicolumn{3}{c}{ Korelasi Ketinggian Lahan } \\
\hline Surface & Pearson & -0.577 \\
Temperature & Correlation & \\
Landsat 7 ETM & & \\
\hline
\end{tabular}

Jika koefisien korelasinya bertanda (-), artinya hubungan suhu permukaan dengan ketinggian berkebalikan arah, dimana semakin tinggi suatu titik maka suhu akan semakin rendah.

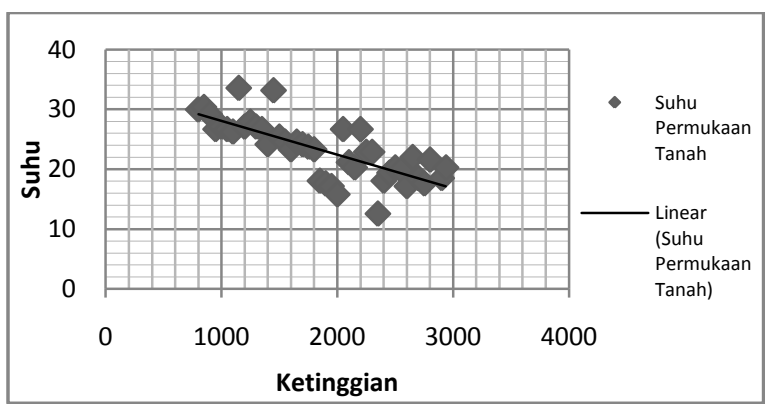

Gambar 5. Grafik Hubungan Suhu Permukaan Tanah dan Ketinggian Lahan

\section{Analisa Potensi Panas Bumi}

Berdasarkan penelitian terdahulu mengenai potensi panas bumi di Kecamatan Sempol, dinyatakan bahwa daerah ljen mempunyai potensi sumber daya panas bumi yang dapat membangkitkan energi listrik melalui Pembangkit Listrik Tenaga Panas Bumi dengan kapasitas $2 \mathrm{x}$ $55 \mathrm{MW}$ (Utama, 2010).

Kegiatan pembangunan power plant meliputi detail engineering design (gambar turbin, generator, condenser, cooling tower, control system, electrical system, power system, instrumentation, turbine building, dII), pembelian (purchase order) material, manufacturing, mobilitas dan pelaksanaan kontruksi sipil, power plant, swicth yard. Berdasarkan temperatur reservoir sebesar $250^{\circ} \mathrm{C}$ maka pembangkit yang digunakan pada PLTP Blawan-ljen adalah Separated Steam Cycle. PLTP akan menggunakan turbin $60 \mathrm{MW}$, sesuai dengan kapasitas PLTP yang akan dikembangkan yaitu 2 × $30 \mathrm{MW}$.

Jenis turbin yang direncanakan dalam pengembangan WKP panas bumi Blawan-ljen adalah Turbine Condensing Type dengan spesifikasi sebagai berikut :

$\begin{array}{ll}\text { Output } & : 2 \times 30 \mathrm{MW} \text { (2 unit) } \\ \text { Pressure } & : 10 \mathrm{bar} . \mathrm{abs} \\ \text { Inlet Temperatur } & : 179^{\circ} \mathrm{C} \\ \text { Exhaust Steam Pressure }: 0.1 \mathrm{bar} \\ \text { Condensing Pressure } & : 0.1 \mathrm{bar} \\ \text { Generator } & : 2 \times 30 \mathrm{Mwe}\end{array}$

Faktor kapasitas PLTP direncanakan 90\% (Utama, 2010)

Untuk kegiatan tertentu yang mengandung dampak besar dan penting terhadap lingkungan (seperti pemboran eksplorasi panas bumi) diperlukan suatu kajian khusus yang dikenal dengan sebutan Analisa Mengenai Dampak Lingkungan (AMDAL). Studi AMDAL pada masa produksi secara lengkap termasuk RPL dan RKL difokuskan pada dampak rencana pengembangan Total proyek. Subyek yang dibahas dan dirumuskan solusinya termasuk aspek pencegahan saat perencanaan, konsep antisipasi dan solusi penanganan kejadian saat pelaksanaan kegiatan operasi dan metode mentoring. 


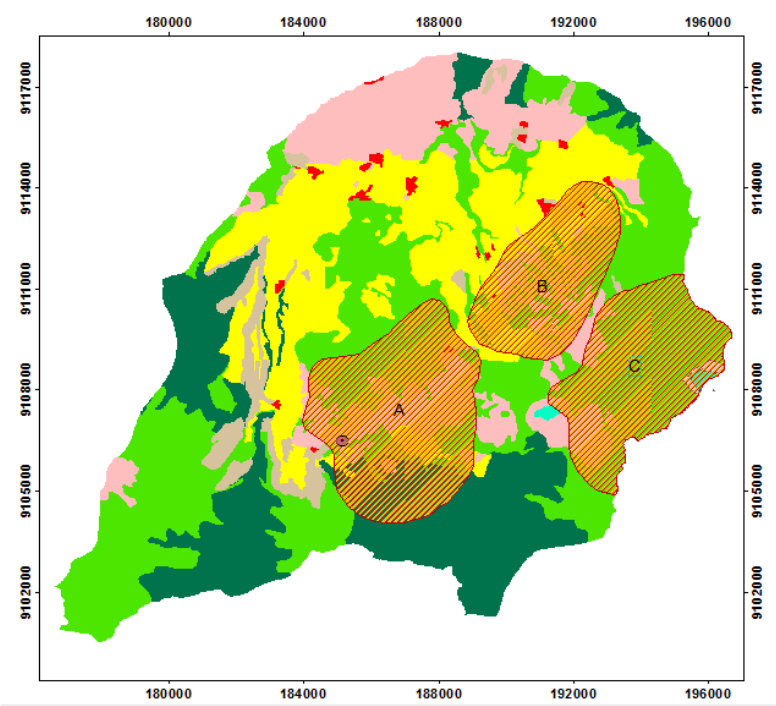

Gambar 6. Lokasi Potensi Panas Bumi (Utama, 2010)

Tabel 5. Hubungan antara suhu permukan, ketinggian dan tutupan lahan pada area prospek
Analisa Kondisi Tutupan Lahan dan Jarak Lokasi Potensi Panas Bumi Dengan Daerah Sensitif Dengan Memanfaatkan Sistem Informasi

\section{Geografis}

Kondisi tutupan lahan pada masing-masing area prospek panas bumi diperoleh dengan overlay pada peta tutupan lahan, sehingga didapat luasan pada setiap kelas tutupan lahan sebagai berikut.

Tabel 5. Kondisi Tutupan Lahan pada Wilayah Prospek A

\begin{tabular}{clrr}
\hline No. & Penggunaan Lahan & Luas (ha) & \multicolumn{1}{c}{$\%$} \\
\hline 1 & Semak Belukar & 1025.95 & 42.53 \\
2 & Tegalan & 26.55 & 1.10 \\
3 & Pemukiman & 4.08 & 0.16 \\
4 & Padang Rumput & 683.34 & 28.32 \\
5 & Kebun kopi & 151.80 & 6.29 \\
6 & Hutan rimba & 520.39 & 21.57 \\
& Jumlah & 2412.13 & \\
\hline
\end{tabular}

Tabel 6. Kondisi Tutupan Lahan pada Wilayah Prospek B tegalan, pemukiman, padang rumput, kebun kopi, hutan

\begin{tabular}{clrr}
\hline No. & Penggunaan Lahan & Luas (ha) & \multicolumn{1}{c}{$\%$} \\
\hline 1 & Semak Belukar & 502.04 & 34.64 \\
2 & Tegalan & 45.75 & 3.15 \\
3 & Pemukiman & 4.06 & 0.28 \\
4 & Padang Rumput & 329.17 & 22.71 \\
5 & Kebun & 568.22 & 39.20 \\
& Jumlah & 1449.27 & \\
\hline
\end{tabular}

3 C $12-40 \quad 1550$ 2362.5

rimba

semak belukar, tegalan, pemukiman, padang rumput, kebun semak belukar, vegetasi non budidaya, tegalan, Tabel 7. Kondisi Tutupan Lahan pada Wilayah padang rumput, Prospek $\mathrm{C}$ kawah

Berdasarkan analisa kondisi tutupan lahan dan klasifikasi ketinggian, lokasi yang cocok sebagai powerplant terletak pada area prospek A karena area tersebut cenderung landai sehingga memungkinkan untuk pembangunan powerplant. Area prospek B kurang cocok sebagai lokasi powerplant karena sebagian besar dari area tersebut merupakan daerah perbukitan. Sedangkan pada area prospek $\mathrm{C}$ terdapat gunung dan kawah ijen yang juga merupakan cagar alam taman wisata ljen.

\begin{tabular}{clrr}
\hline No. & Penggunaan Lahan & Luas (ha) & \multicolumn{1}{c}{$\%$} \\
\hline 1 & Semak Belukar & 1532.89 & 81.77 \\
2 & Vegetasi Non Budidaya & 35.52 & 1.89 \\
3 & Tegalan & 0.28 & 0.01 \\
4 & Padang Rumput & 276.16 & 14.73 \\
5 & Kawah & 29.68 & 1.58 \\
& Jumlah & 1874.56 & \\
\hline
\end{tabular}

Jarak lokasi titik pengeboran sumur dengan daerah sensitif diperoleh dengan menggunakan analisa proximity-near. 
Tabel 8. Jarak terdekat daerah-daerah sensitif dengan titik sumur pengeboran

\begin{tabular}{clc}
\hline No. & Nama & Jarak (meter) \\
\hline 1 & Jalan Lokal & 5953.485582 \\
2 & Jalan Setapak & 1022.018273 \\
3 & Sungai & 845.071247 \\
4 & Pemukiman & 689.920792 \\
5 & Kebun & 225.516922 \\
6 & Mata air & 4440.704143 \\
\hline
\end{tabular}

Pada peta tutupan lahan ditunjukkan terdapat pemukiman penduduk (Dusun Curah Macan, Desa kalianyar) di dalam area pengeboran, namun titik pengeboran sendiri berjarak lebih dari $600 \mathrm{~m}$ dari Dusun Jampit. Selain itu mata air dari Dusun Jampit yang berjarak $4 \mathrm{~km}$ diambil sebagai sumber air proses pengeboran.

\section{KESIMPULAN}

a. Hasil korelasi antara suhu permukaan dengan ketinggian termasuk tingkat korelasi sedang ($0,40--0,599)$. Koefisien korelasinya bertanda $(-)$, artinya hubungan suhu permukaan dengan ketinggian lahan berlawanan arah, sehingga jika suhu permukaan semakin tinggi, maka ketinggian lahan akan semakin rendah.

b. Potensi sumber daya panas bumi yang dapat membangkitkan energi listrik melalui Pembangkit Listrik Tenaga Panas Bumi dengan kapasitas 2 x $55 \mathrm{MW}$.

c. Penggunaan lahan pada daerah pengembangan potensi panas bumi terdiri dari beberapa jenis tutupan lahan, yaitu semak belukar, tegalan, pemukiman, padang rumput, kebun, hutan rimba, vegetasi non budidaya, dan kawah. Dengan didominasi oleh semak belukar 53,36\% dengan luas 3060,89 ha.

d. Area prospek yang sesuai untuk kegiatan pembangunan powerplant adalah area prospek A, karena area tersebut cenderung landai dengan ketinggian antara 1400 - 1850 meter. Sedangkan area prospek B dan C tidak sesuai sebagai lokasi powerplant karena sebagian besar dari area tersebut merupakan daerah perbukitan dan terdapat gunung dan kawah ijen yang juga merupakan cagar alam taman wisata ljen

\section{DAFTAR PUSTAKA}

Saptadji, Nenny. Teknik Panas Bumi. ITB

Sukojo, B. M. 2012. Penginderaan Jauh (Dasar Teori \& Terapan). Surabaya : ITS-Press.

Rodrigue. 2000. Vertical Thermal Structure Of The Atmosphere

Wahyudi. 2005. Kajian Potensi Panas Bumi Dan Rekomendasi Pemanfaatannya Pada Daerah Prospek Gunungapi Ungaran Jawa Tengah. Jurusan Fisika, FMIPA-UGM, Yogyakarta

Utama, Widya. 2010. Perencanaan Dan Program Kerja Pengembangan Panas Bumi Di Wkp Blawan Ijen. ITS

Usman, Husaini dan Purnomo, Setiadi Akbar. 2006. Pengantar Statistik. Jakarta: PT. Bumi Aksara.

Sugiyono. 2007. Hipotesis Statistik. Bandung: Universitas Pendidikan Indonesia.

\section{LAMPIRAN}
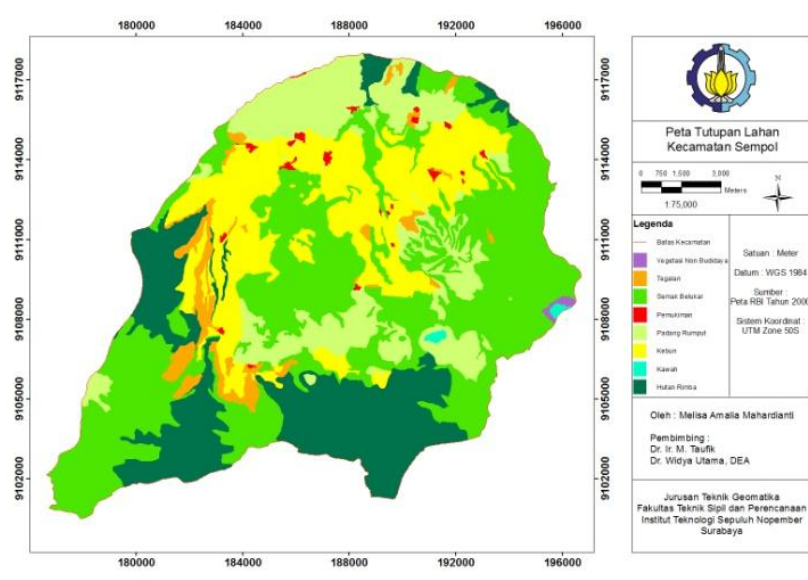

Gambar 7. Peta Tutupan Lahan Kecamatan Sempol tahun 2000

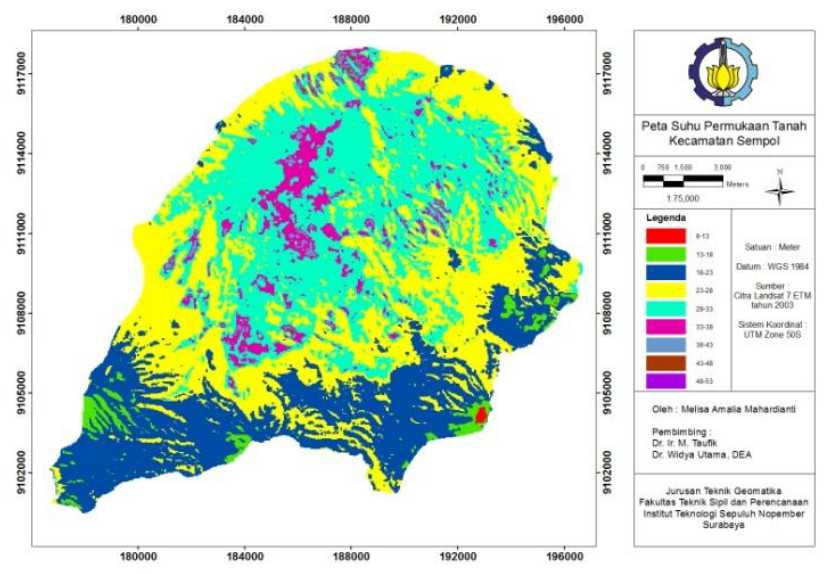

Gambar 8. Peta Suhu Permukaan Tanah Kecamatan Sempol tahun 2003 


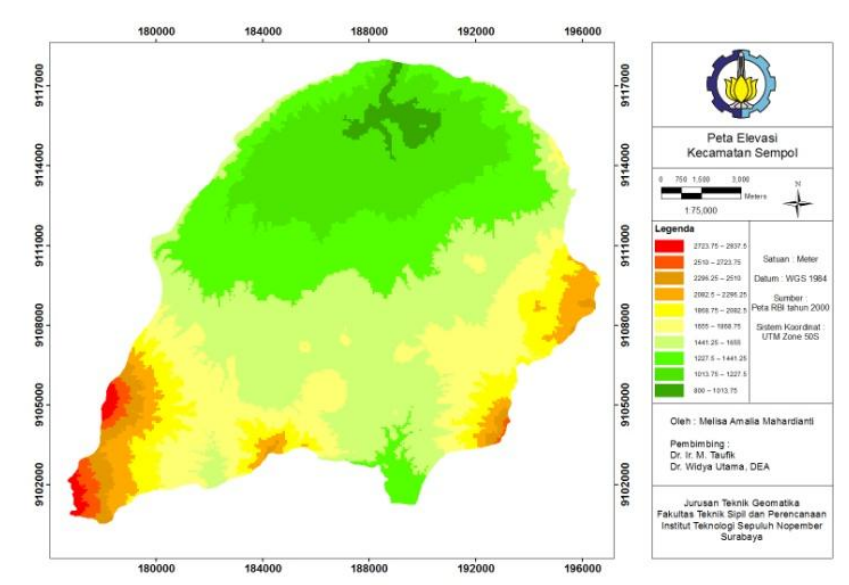

Gambar 9. Peta Ketinggian Lahan Kecamatan Sempol 